\title{
ROCKY MOUNTAIN SPOTTED FEVER IN THE RABBIT.*
}

\section{LIBORIO GOMEZ.}

(Manila, P. I.)

(From the Departments of Palhology and Experimental Therapy, the University of Chicago.)

THE first inoculation of rabbits made with the so-called "Rocky Mountain Spotted Fever" is mentioned by Wilson and Chowning in their paper on Piroplasmosis hominis. One of their animals which was inoculated with 20 c.c. of blood from a human case died after eight days, showing on autopsy hemorrhagic areas under the skin, enlargement of the spleen, and hemorrhage into the kidney.

Ricketts, ${ }^{2}$ in r 906 , did not get positive results by the inoculation of rabbits with I c.c. and 4 c.c. respectively of defibrinated blood from two human patients. In one rabbit, however, he noticed a rise of temperature for about two or three days, four or five days after inoculation.

In a recent paper, Ricketts and Gomez ${ }^{3}$ stated that the rabbit had been found susceptible to the virus as cultivated for a long time in the guinea-pig. The successive passage of the virus through the guinea-pig may have modified it in such a way that it became more virulent to the rabbit.

It is the purpose of this paper to describe features of the disease in rabbits as observed in recent experiments undertaken at the suggestion of Professor H. T. Ricketts.

CLINICAL AND PATHOLOGICAL PHENOMENA.

After the inoculation of 0.5 to I c.c. of virus (defibrinated blood from infected guinea-pigs, drawn on the third or fourth day of fever) there occurs an incubation period of three to six days, marked by a slight rise of temperature which sometimes reaches $104^{\circ} \mathrm{F}$. for one or two days, and then subsides before the fever of general invasion sets in. The latter is marked by a sudden rise in temperature to $104^{\circ}-105^{\circ} \mathrm{F}$, rarely higher, which persists for three to five days, after which it falls usually by lysis.

* Received for publication April $2 \mathrm{r}$, inon-

Iour. Infect. Dis., I904, I, p. 48.

3 Jour. Infect. Dis., Igo8, 5, p. $22 \mathrm{y}$.

a Jour. Amer, Med. Assoc., 47, D. 36. 
The rabbit, during the course of the disease, so far as weight and general health are concerned, is not profoundly affected, as a rule. The scrotum often becomes congested. One rabbit which died after withdrawal of blood from the heart showed petechial hemorrhages in the scrotum.

At autopsy the only gross changes found are the enlargement of the spleen and to a slight extent of the lymph glands. The spleen is also darker in color and softcr in consistency than the normal organ. Other viscera do not show changes detectable to the naked eye.

The blood of the rabbit during the height of the disease is infective for the guinea-pig. For example, a rabbit which was inoculated intraperitoneally with 5 c.c. of virus had the following temperatures on successive days: $103.4,103,103.3,102.2,105.8,104.9,105.6$, I05.7. Death followed from hemopericardium as a result of bleeding from the heart.

On the first day of fever, five days after inoculation, blood was drawn from the heart and injected into Guinea-pig 1,010 which ran the following course of fever on successive days: I02.8, I02.6, Іо3. I, I02.7, 105.6, 105.9, 105.8, 105.7, 105.8, 104.8, 104.8, 103, г03.6.

At autopsy the scrotum was hemorrhagic and gangrenous, and the ears gangrenous.

The blood of Rabbit I2, which showed a low degree of fever, was infective I2 days after inoculation. The following course of fever was shown by the rabbit on successive days: 103.3, 103, 103, I04, I04.2, I05, I04.8, —, I04.4, I03.6, I03.2, recovery.

Guinea-pig $I, 176$, which received 2 c.c. of fresh undefibrinated blood from Rabbit 12 on the I 2 th day after inoculation, had fever as follows: 104, 104.2, 104.6, —, 104.8, 104, 105.4, 105.6, 104, ror $4,98.8$, death.

At autopsy the spleen and lymph glands were found to be enormously enlarged, the adrenals showed punctiform hemorrhages, and the scrotum was congested and gangrenous.

Out of about $\mathbf{r} 8$ rabbits inoculated with the virus of spotted fever only one death could be ascribed to the disease, and this occurred i 7 days after inoculation. After recovery many of the rabbits died from adventitious infections.

It has been possible to transmit the disease from one rabbit to 
another six times by inoculating blood from the infected animal at the second to fourth day of high fever. Unfortunately the seventh rabbit that was inoculated died from an adventitious infection during the incubation period so that no conclusion can be reached as to how far the disease may be transmitted from one rabbit to another taking the temperature as the index of the disease.

\section{IMMUNITY IN THE RABBIT.}

The blood of animals that have recovered from the disease contains protective antibodies in contrast to the blood of the normal rabbit. It has been found that 0.05 c.c. of defibrinated blood from the rabbit which has recovered affords a slight protection; o. I c.c. moderate and 0.3 c.c. complete protection against I c.c. of infected blood from the guinea-pig. This is shown in Tables I and 2.

The experiment illustrated in Table I shows that normal rabbit blood has little or no protective power for the guinea-pig.

\section{TABLE 1 .}

Protective Power of Normal Rabbit Biood.

Virus from Guinea-pig 13 R, 3 d day of fever: I c.c.*

Normal rabbit blood in yarying amounts.

Virus and blood mixed before injection, and the residue washed with salt solution and injected intraperitoncally

Test animals: guinea-pigs.

\begin{tabular}{|c|c|c|c|c|c|c|c|}
\hline & \multirow[t]{2}{*}{$\begin{array}{l}\text { DATE } \\
\text { I008 }\end{array}$} & \multicolumn{2}{|c|}{$\begin{array}{c}\text { Guinea-Pig } 2 \text { i R; Nok- } \\
\text { Mai. RabBit Bloon, } \\
0.3 \text { C.C. }\end{array}$} & \multicolumn{2}{|c|}{$\begin{array}{l}\text { Guinea-Pig } 22 \text { R; Nok- } \\
\text { MaL RabBit BLOOD, } \\
\text { I c.C. }\end{array}$} & \multicolumn{2}{|c|}{$\begin{array}{l}\text { GUINEA-PIG } 20 \mathrm{R} \text {; CON- } \\
\text { IROL; VIRUS ALONE: } \\
\text { I C.C. }\end{array}$} \\
\hline & & Temp. & Remarks & Temp. & Remarks & Temp. & Remarks \\
\hline 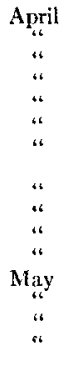 & 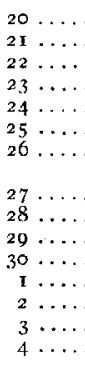 & $\begin{array}{l}\ldots \ldots \\
103.6 \\
103.0 \\
\ldots \ldots \\
105.4 \\
\ldots \ldots .6 \\
105.6 \\
106.0 \\
105.4 \\
\ldots \ldots \\
105.0 \\
104.0 \\
103.8 \\
\ldots \ldots 2 \\
102.8\end{array}$ & $\begin{array}{l}\text { Severe course } \\
\text { of fever; } \\
\text { gangrene of } \\
\text { ears; no } \\
\text { changes in } \\
\text { genitalia; re- } \\
\text { covery }\end{array}$ & $\begin{array}{l}\ldots \ldots \\
104.2 \\
102.8 \\
\ldots \ldots \\
106.2 \\
\ldots \ldots 6 \\
106.0 \\
106.3 \\
105.2 \\
\ldots \ldots \\
\text { Io2.0 } \\
\text { Died }\end{array}$ & $\begin{array}{l}\text { Autopsy } \\
\text { typical for } \\
\text { spotted fever }\end{array}$ & $\begin{array}{l}\ldots \ldots \\
\text { 103.0 } \\
103.2 \\
\ldots \ldots . \\
\text { I05.6 } \\
\ldots \ldots .8 \\
\text { Ios.8 } \\
\text { Killed }\end{array}$ & $\begin{array}{l}\text { Autopsy } \\
\text { typical for } \\
\text { early spotted } \\
\text { fever }\end{array}$ \\
\hline
\end{tabular}

* Representing approximatedy 100 pathogenic doses. 
TABLE $z$.

Protective Power of the Broon of "Reconered" Rambits.

Virus from 56 th "Eddy" passage: I c.c.*

Immune defibrinated blood from "recovered" rabbits: varying amounts.

Immune blood and virus mixed before injection, and the residue washed with salt solution and injected intraperitoneally

Test animals: guinea-pigs.

\begin{tabular}{|c|c|c|c|c|c|c|c|c|}
\hline \multirow[t]{2}{*}{$\begin{array}{l}\text { DATE } \\
\text { I908 }\end{array}$} & \multicolumn{2}{|c|}{$\begin{array}{l}\text { GUINEA-PIG II R; } \\
\text { IMMUNE BLOOD, } \\
\text { O.5 C.C., FROM RAB- } \\
\text { BIT 2 I, 8 DAYS AFTER } \\
\text { SUBSIDENCE OF } \\
\text { FEVER }\end{array}$} & \multicolumn{2}{|c|}{$\begin{array}{l}\text { GUINFA-PIG } 8 \text { R; } \\
\text { IMMUNE BIOOOD, } \\
\text { O. I C.C, FROM RAB- } \\
\text { BIT 21, } 26 \text { DAYS ATTER } \\
\text { SURSIDENCE OF } \\
\text { HIGH FEVER }\end{array}$} & \multicolumn{2}{|c|}{$\begin{array}{c}\text { GUINEA-PIG 0 R; } \\
\text { IMMUNE BIOOD, } \\
\text { O.3 C C., FROM RAB- } \\
\text { BIT } 21\end{array}$} & \multicolumn{2}{|c|}{$\begin{array}{l}\text { Control; VIRUS } \\
\text { AI.ONE, O.OI C.C. } \\
\text { GUINEA-PIG } 16 \mathrm{R}\end{array}$} \\
\hline & Temp. & Remarks & Temp. & Remarks & Temp. & Remarks & Temp. & Remarks \\
\hline 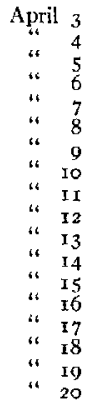 & $\begin{array}{l}104.2 \\
104.4 \\
\ldots \ldots . \\
104.8 \\
105.0 \\
105.0 \\
104.2 \\
\ldots \ldots \\
\ldots \ldots \\
103.4 \\
102.0\end{array}$ & $\begin{array}{l}\text { Mild course } \\
\text { of spotted } \\
\text { fever; scro- } \\
\text { tum swollen; } \\
\text { recovery }\end{array}$ & $\begin{array}{c}\ldots \ldots \\
\ldots \ldots \\
102.0 \\
103.2 \\
\ldots \ldots \\
103.2 \\
\ldots \ldots \\
103.4 \\
103.6 \\
\ldots \ldots \\
104.0 \\
104.3 \\
105.4 \\
104.0 \\
\ldots \ldots \\
10.6 \\
103.5 \\
102.6\end{array}$ & $\begin{array}{l}\text { Short course } \\
\text { of mild fever; } \\
\text { recovery; no } \\
\text { changes in } \\
\text { genitalia }\end{array}$ & $\begin{array}{l}\ldots \ldots \\
\ldots \ldots . \\
103.4 \\
104.8 \\
\ldots \ldots .6 \\
103.6 \\
\ldots \ldots . \\
103.2 \\
102.6 \\
\ldots \ldots .6 \\
102.6 \\
103.2 \\
102.7 \\
103.0 \\
\ldots \ldots \\
\ldots \ldots \\
103.4 \\
104.2\end{array}$ & $\begin{array}{l}\text { No distinct } \\
\text { course of } \\
\text { fever; irreg- } \\
\text { ular rises } \\
\text { probably ac- } \\
\text { cidental; } \\
\text { recovery; no } \\
\text { changes in } \\
\text { genitalia }\end{array}$ & $\begin{array}{l}\ldots \ldots \\
\ldots \ldots \\
103.6 \\
\text { I04.4 } \\
\ldots \ldots . \\
\text { I03.8 } \\
\ldots \ldots . \\
104.5 \\
106.6 \\
\ldots \ldots . \\
\text { 107.2 } \\
104.8 \\
106.2 \\
\text { 103.4 } \\
\ldots \ldots . \\
\ldots \ldots 3 \\
103.5 \\
\text { I03.2 }\end{array}$ & $\begin{array}{l}\text { Severe course } \\
\text { of fever; re- } \\
\text { covery; } \\
\text { scrotum and } \\
\text { cars gan- } \\
\text { grenous; } \\
\text { immunity } \\
\text { test, May } 26 \text {; } \\
\text { no fever } \\
\text { developed }\end{array}$ \\
\hline
\end{tabular}

* Representing approximately 100 pathogenic doses

\section{SUMMARY.}

The rabbit is susceptible to the virus of Rocky Mountain spotted fever as cultivated for a long time in the guinea-pig. The disease is milder in its symptoms than that produced in the monkey and guineapig. The blood of rabbits at the height of the disease is infective for guinea-pigs. It has been possible to transmit the disease from one rabbit to another through six animals successively. The blood of rabbits which have recovered contains bodies which protect against the disease, such bodies being largely or entirely absent from the blood of normal rabbits. 